\title{
Publisher Correction: How we started CSCW
}

Irene Greif

Correction to: Nature Electronics https://doi.org/10.1038/s41928-019-0229-y, published online 18 March 2019.

Owing to a technical error, the 'Published online' date of this Reverse Engineering originally mistakenly appeared as '15 March 2019', but should have been '18 March 2019'. 